\title{
The Implementation of Principal Managerial Competence for the Primary School Student Discipline
}

\author{
Aceng Jaelani ${ }^{1}$, Patimah", ${ }^{1, *}$ Uci Sanusi ${ }^{2}$, Ahmad Arifuddin ${ }^{1}$ \\ ${ }^{1}$ Department of Madrasah Ibtidaiyah Teacher Education, Institut Agama Islam Negeri Syekh Nurjati Cirebon, 45132, West Java, Indonesia \\ ${ }^{2}$ Department of Elementary School Teacher Education, STKIP Muhammadiyah Kuningan, 45511, West Java, Indonesia
}

Copyright $(2019$ by authors, all rights reserved. Authors agree that this article remains permanently open access under the terms of the Creative Commons Attribution License 4.0 International License

\begin{abstract}
The principal has a significant role in coordinating, mobilizing and harmonizing all available educational resources in school. All these educational resources cannot run optimally without competent management by the principal. This study aims to describe the managerial competence of the principal at Madrasah Ibtidaiyah (Islamic Primary School) Darul Masholeh of Cirebon City, West Java, Indonesia, the implementation of student discipline, and the factors that influence the implementation of student discipline. This research is qualitative research with data collection techniques in the form of interviews, observation and documentation. The subjects of this study were principals, teachers, students and parents of Madrasah Ibtidaiyah (Islamic Primary School) Darul Masholeh of Cirebon City, West Java, Indonesia. The research data were analyzed using qualitative descriptive analysis. The results of the study show that principals have been able to build a good school system in improving the quality of education in their schools. Furthermore, the implementation of student discipline in schools has also been going well. As for the factors that influence the implementation of disciplinary students to include internal factors of students, school environmental factors, attention factors and parenting (family).
\end{abstract}

Keywords Principal Managerial Competence, Student Discipline, Factors that Influence It

\section{Introduction}

In line with the challenges and global life, education is essential, because education is one of the determinants of the quality of human resources. The abundance of natural wealth no longer marks the superiority of a nation, but the advantage of human resources. One of the most important human resources in achieving the goals of education in a school is the principal [1]. According to Mulyasa [2], the principal has role and function as an Educator, Manager, Administrator, Supervisor, Leader, Innovator, and Motivator (EMASLIM). For this reason, each school principal must understand his role and function as headmaster [3]. The ability that must be realized by the principal as a leader can be analyzed from personality, education knowledge, vision and mission of the school, the ability to make decisions, and communication skills. According to Wahjosumidjo [4], managerial competence is a skill or particular ability possessed by managers in the process of planning, organizing, leading and controlling the efforts of members of the organization and utilization of all resources to achieve the goals. Werang [5] added that managerial competence refers to the skills of school principals in managing all school resources to improve the effectiveness and efficiency of school work. For this reason, principals as education managers should have managerial competencies which include conceptual, human skills and technical skills [6]. In addition, according to Badarrusaleh [7], managerial skills of principals include planning skills, skills in organizing resources, skills in carrying out activities, and skills in conducting control and evaluation.

Furthermore, according to Tu'u [8], discipline is something that is concerned with one's self-control of the forms of rules. The same thing was also conveyed by Gunarsa [9] who stated that discipline is an awareness to do everything in an orderly manner by the applicable regulations responsibly without any coercion from any party. Meanwhile, Suradi [10] suggests that discipline is a condition that is created and formed through the process of a series of individual behaviors that show the values of obedience, loyalty, and order. This discipline is very closely related to obeying the rules. Discipline is always taught to people who are always on time, obedient to the rules, and behave abiding by applicable norms [11].

According to Efendi [12], regulations are formalized guidelines in describing behavior in both justified and not justified. The rule aims to guide and limit students' 
behavior in a positive direction [13]. One of the rules in school is discipline. School discipline is a collection of rules that must be adhered to and carried out in schools by all students so that learning runs smoothly [14]. Each student must be introduced to the rules and endeavored to be able to understand the benefits or uses so that the rules can be carried out without coercion. The effort to create and enforce regulations is a school activity in outlining restrictions by telling students what to expect and why this is needed.

In their research, Sugeng [15], Iriawan [16], Werang [5] revealed that managerial competencies of principals contribute positively to teachers' performance and social competence. Educators (including principals) also have a significant role in providing examples of discipline for students [17]. The form of controlling students in school can be in the form of punishment in maintaining environmental cleanliness, attitude discipline, and cleanliness in-class hours [18].

Based on the results of observations conducted by researchers, it was shown that the Principal of MI (Islamic Elementary School) Darul Masholeh Cirebon City has complied with the standards of school principals in accordance with Minister of Education and Culture Regulation (PERMENDIKBUD) No. 13 of 2007 Challenging Principal Standards. However, researchers still find various disciplinary problems that occur in the madrasa, for example, some students wear uniforms which are not based on the schedules; there are students whose attendance are not maximal (skipping in the middle of class); and there are students who arrive late at school. Besides, in their daily lives, students are often late in class after recess. This is in line with the research conducted by Ariananda et.al. [14], Latifah \& Nuraida [19] which concluded that the discipline of students in schools is still lacking. This study aims to describe the managerial competence of the principal, the implementation of student discipline, and the factors that influence the implementation of student discipline in school.

\section{Methods}

In this study, the researcher used a qualitative approach. According to Sugiyono [20], qualitative research is a study that is used to examine natural objects where the researcher is the key, and the result is a description of words that describe an object or event. In this qualitative research, data was interpreted as facts or information obtained from actors (research subjects, informants, or actors), activities, and places that are the subject of the research. The subjects of this study were principals, teachers, students and parents of MI Darul Masholeh Cirebon City. Meanwhile, data collection techniques used in this study are observation techniques, interviews (interviews), and documentation.

The observation technique was used to photograph the implementation of student discipline at MI Darul Masholeh. Meanwhile, interview techniques are used to explore data on the implementation of managerial competencies of the principal while at the same time digging data on the factors that influence the implementation of student discipline at school. However, the documentation technique is used to obtain data on students, teachers, principals and profiles of MI Darul Masholeh. Validity Data in this study was applied through the stages of extension of observation, increasing persistence, and triangulation of data.

The results of the research data were then analyzed using qualitative data analysis perspectives [21], namely the activity in analyzing the data is carried out continuously to completion, and the data is saturated. Qualitative data analysis also starts from data collection, then reduces data, then presents data, and finally draws conclusions from all the things that are the focus of the study.

\section{Results}

\subsection{Implementation of Principal Managerial Competence}

Increasing the performance of teachers and education staff is always carried out by the Principal of MI Darul Masholeh Cirebon City. The principal always strives to improve the ability of all teachers by allowing teachers to attend training, seminars and other activities that can improve their competence as a teacher. The development of teachers' competencies is carried out by their respective knowledge [22]. The principal also always communicates with the teacher regarding the problems of classroom learning, students' development, and teachers' professionalism. All these things are done by giving direction, motivation and providing solutions when the teacher gets into trouble. On the other hand, a teacher also has his responsibility to improve competence in their respective fields, to be able to provide excellent service for anyone with interest in our school. For example, the teacher must learn a lot about teaching approaches, learning methods, and teaching media, so that students who learn feel challenged and motivated to pay attention and serious learning and understand what is taught by the teacher (interview with grade IV teachers).

In terms of a managerial discipline of students, each teacher and principal is obliged to provide character education in various ways by using the right opportunity as an effort to improve the behavior and character of students. Teachers must be smart to associate subject matter with the context of daily life so that students easily understand and apply it in everyday life. Besides, the principal always checks and monitors whether this was done or not, namely by examining learning administration such as lesson plan, semester and annual program, and other learning aids. Besides, the principal also always supervises by seeing the 
learning process carried out directly by the teacher in the class (interview with the principal).

In addition, the role of parents as the primary supervisor for the development of their children is to report changes in the daily behavior of children at home as an evaluation of the school. Besides, it is also through joint meetings between parents/ guardians of students with the school, parent meetings with homeroom teachers and making school committees or class committees as a container for the parents' aspirations to the school or vice versa if there is information from the school through the school committee or class committee. Beside meetings, communication between the school and parents is also done through the application of social media to make it more effective and efficient (interview with the principal). The implementation of principal managerial competence in MI Darul Masholeh can be described as chart 1 below.

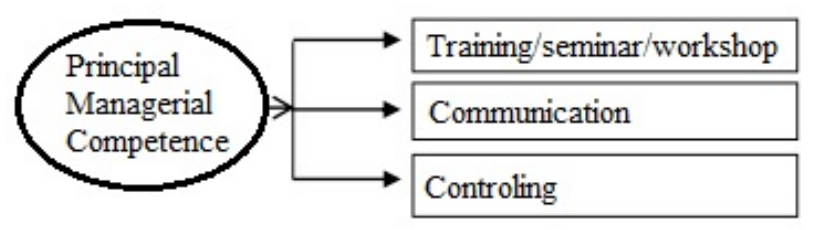

Chart 1. The implementation of principal managerial competence

\subsection{Steps of the Principal in Embedding Student Discipline}

The actions taken by the principal in instilling discipline into MI Darul Masholeh students are: First, the principal identifies undisciplined student behavior such as students not doing assignments, fighting in class, not neatly in dress, forget not to bring a textbook, and not carry out pickets. The teacher or headmaster then give this student's lack of discipline an action; Second, principal makes student discipline rules and specific class rules based on identified student problems. The established rules made by the teacher are the development of school discipline and adjustments to the behavior of students in the classroom. The implementation of school rules and class rules was made so that problems that occur in the class were reduced; Third, the rules that the teacher socializes are made for students. The way that teachers adopt to socialize is to write the rules which are then attached to the wall so that students easily remember them. Also, regulations that were made are delivered verbally in class. This was done from first grade to sixth grade. The socialization is carried out in the form of slogans and posted on a bulletin board also in a place that is easy to read by students.

Fourth, the principal gives sanctions to students who violate the rules that have been made. Sanctions are provided not only by the teacher but also provided by the principal. Sanctions are in the form of looking for trash around the class, giving fines, making statements not to repeat their actions, adding to the burden of the task when there are students not doing the assignment; and fifth, the principal gives a warning to students who violate the rules. This was done so that students do not repeat the process. The advice given to students serves as a break in carrying out actions; actions that should be done by students are actions that do not hurt themselves and others. Things that can harm themselves are lazy to learn, not doing assignments, fighting, and not carrying books and others. While actions that harm other people are exploiting friends, playing with sharp tools, being noisy in class and other actions. The usual warning forms at MI Darul Masholeh are frequent warnings when students violate disciplines in the way of sayings, written warnings 1 to written warnings 3.

\subsection{Implementation of Student Dicipline of MI Darul Masholeh Cirebon City}

Instilling discipline in students at MI Darul Masholeh Cirebon City carried out in various ways, including the cultivation of disciplinary characters during class hours, extra-curricular scouts, habituation of schools such as flag ceremonies every Monday, the implementation of Dhuha prayers, praying before and after lessons and Friday Clean and Healthy (JBS). All of these things were done with the aim that all students have good habits and have a disciplined character that will have implications for the mature personality of the student (interview with the vice principal of the student field).

Meanwhile, according to homeroom 3 and 4, MI Darul Masholeh expressed that instilling the character of student discipline can also be done through collaboration with parents of students. The role of parents of students in instilling the character of student discipline is always to monitor the development of students, pay attention to their behavior such as speaking, praying, and behaving politely towards others. Communication between parents and the school on instilling the character of discipline is also done through social media groups by giving appeals and warnings and reports of children every day.

The types of disciplinary violations of students at MI Darul Masholeh are indeed quite diverse; there are some that are general violations or violations that are specified by the class level and the development process. Types of violations of broad student discipline include such as skipping school, wearing uniforms and school attributes that are not by their schedules, and being late for school. While the types of student disciplinary violations are specified by the class level and its development, for example, students in grades 1-4 students tend to fight and mock each other because of their ego. It is similar to what was conveyed by homeroom teacher one that class 1 students tend to have strong ego and it was motivated by the position of children in families who are mainly the youngest children or the last child in the family. Whereas for the upper class they do not wear uniforms according to 
schedule, clothes that are not included, skipping do not enter the class and provoking improper students. Whereas type 3 is more often late for class after recess and does not do assignments and does not carry the scheduled book. As for grade 6 on the level of attendance of students in the class, students often skip class, and have long hair and long nails.

According to the Principal of MI Darul Masholeh, implementing the discipline of students at MI Darul Masholeh includes four elements, namely the application of regulations, punishment, appreciation, and consistency. First, the application of school regulations. The school regulations that have prepared must be understood and implemented by all school members. If there are school members (including students) violating school rules, then they must accept the consequences, so that school regulations that have been made can provide justice for all. Second, give punishment. How to discipline students in the form of sanctions and coaching? For example, by giving advice, reprimand, emphasizing to students and reminding students about school discipline at all times. Sanctions are given to students who violate discipline in the form of words and commands that educate as a form of coaching and make students aware of wrong behavior. Forms of punishment vary according to the type of violation committed by students. According to the deputy principal of the student field, the application of penalties for students is relative, where the punishment was adjusted according to the violation. Giving punishment in Islamic elementary schools /Madrasah Ibtidaiyah schools is not as strict as in junior high school so the sanctions are in the form of reprimand, guidance, and advice. However, if the violation crosses the boundary, then it provides further guidance accompanied by parents who work with the team formed by the school.

Third, award rewards. Give awards to students who were disciplined and achievers performed during flag ceremonies and other activities. The form of the prize can be in the way of words that are congratulations, motivations or in the way of goods/objects. Fourth, consistency in the application of regulations, penalties, and awards. The principal is consistent in applying the rules that have been set for all students. In addition to being consistent, the school principal is also fair in applying school rules to all students. This can be seen from students obeying the rules every day, i.e. disciplined students dress according to schedule and students who throw garbage in its place. The implementation of student discipline of MI Darul Masholeh can be described as chart 2 below:

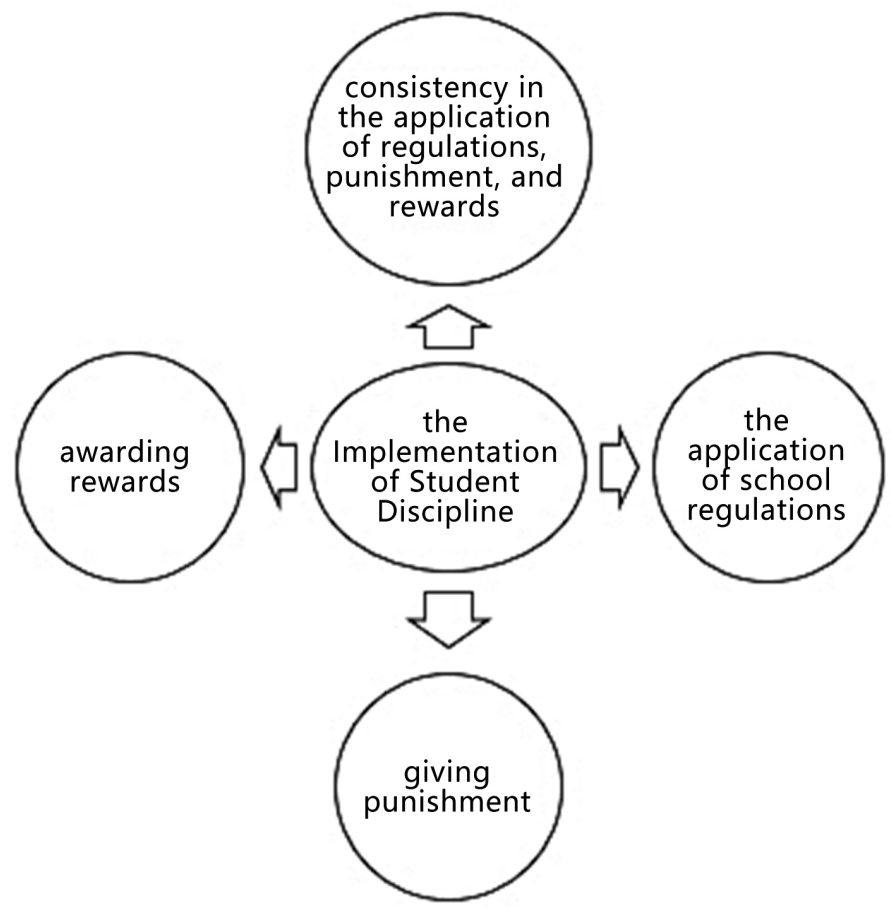

Chart 2. The implementation of discipline students 


\subsection{Factors Affecting Student Discipline}

Factors that influence students' discipline include supporting elements for implementing student discipline and inhibiting factors in achieving student discipline in school. Elements supporting the implementation of student discipline consist of student-derived factors, namely the understanding of students regarding fairly good school rules and school environment factors, where infrastructure such as bells are able to provide information for all students, posters appeals for discipline, examples given by teachers to students as well as optimizing the Smart Indonesia Program (PIP) initiated by the government.

The factors that hinder the implementation of student discipline in schools include that the element of attention of parents (family) to the discipline of their children is still lacking, school buildings are separated and a little far apart, and infrastructure facilities such as school gates/fences have not been closed. Related to the attention factor of the parents (family), the principal added that the parents of MI Darul Mashsoleh students were mostly in the economic and middle to lower education classes. This causes parents to pay less attention to their children so that their child's delinquency is not detected and not appropriately resolved, for example, students do not wear uniforms according to schedule, and students do not carry lesson textbooks and dirty nails and hair. Also, another obstacle is that parenting in disciplining their children is still lacking.

\section{Discussion}

To implement student's discipline, the principal of the MI Darul Masholeh Cirebon City has used management principles. Good and programmed management will determine success in achieving student discipline. The headmaster gives enthusiasm, encouragement, and motivation to the teacher to try to maximize student's discipline because the teacher is in direct contact with students and certainly already knows the character of each student and already has a strategy in implementing discipline that is easily understood by students. This is in line with the results of research conducted by Huang [23], Lourmpas \& Dakopoulou [24], Sugeng [15], Werang [5] which suggested that managerial competence of principals is very influential on teacher's performance. The better the managerial competencies that the head of the school's head has, the better the teacher's performance is. Ariananda et.al[14] also added that the effort that can be made to improve teachers' performance is to encourage teachers to continue learning such as attending workshops, training, and so on. The results of the research conducted by [25],[26],[27],[28] also reveal that the ability of principals and teacher competencies is crucial in the progress of a school.

According to Efendi [12], the principal as a manager has a role in the management of school management. The success or failure of achieving school goals is greatly influenced by the ability of the principal to carry out school management functions, namely planning, organizing, and implementing. The management functions will run when the principal has good managerial competencies who can play educators, managers, administrators, supervisors, leaders, innovators and motivators [2]. School management was also influenced by policies, budgets and academics [29].

Meanwhile, related to the steps in instilling discipline into students, the Principal of MI Darul Masholeh school has set five steps for planting discipline at MI Darul Masholeh, namely first, identifying and analyzing students' bad behavior; second, make school regulations; third, socializing school regulations through interesting slogans; fourth, make consequences / sanctions; and the fifth, gives a warning to students about the rules that have been made. To be able to cope with / minimize the discipline violations of students in schools, principals and teachers must be able to recognize students more closely. This is in accordance with what was stated by Koening [30] that the more teachers recognize students, the more likely the teacher prevents/minimizes the occurrence of violations. Because the teacher is a person who is close to students and knows the character of their students [31].

Furthermore, to implement the discipline of students at MI Darul Masholeh, the principal has implemented it through the application of school regulations, punishments, awards, and consistency of the three things so that all school citizens behave according to existing rules. If the attitudes and behavior of students are right then the rewards will be given. If the attitudes and behavior are negative, then the punishment will be received, so that the three elements are consistent and permanent in their application so that there is a balance between the components of discipline in the school. All of these things will go well if all parties take on the role according to their respective roles and functions [18]. Therefore, the principal of MI Darul Masholeh Cirebon City has implemented discipline for all school residents, namely teachers and students every day. The implementation of the values of discipline in students can be seen from the application of rules, punishments, awards, and consistency that comes from outside of the students. The application of discipline carried out by the principal of MI Darul Masholeh Cirebon City was fair and went well.

Nevertheless, several factors influence the implementation of discipline in MI Darul Masholeh, including the understanding of students regarding school rules, school environment factors, the example of the teacher and the principal, and the attention and upbringing of parents (family). This is similar to what was stated by Slameto [32] that the factors that influence student discipline are internal factors which include physical and psychological factors, as well as external factors which include family factors, school factors and community 
factors. The same thing was also stated by Rohman [17] that the factors that influence the implementation of student discipline include extrinsic factors which were divided into two parts, namely social factor consisting of family, group, community and school and non-social environment factor, such as air condition, temperature, and learning tools used, while for intrinsic factors, namely psychological factors such as interest, talent, concentration, intelligence, and motivation.

In principle, the principal managerial competence that is implemented in MI Darul Masholeh Cirebon City can also be applied in other schools. This can be seen from the results of his research Badarrusaleh[7] that in implementing managerial competence of principals by developing teacher and employee resources through training, seminars, and workshops. Besides, it can also do through good communication between school principals, teachers, and employees. Furthermore, the implementation of principals' managerial competencies is also through monitoring and evaluation activities.

Meanwhile, according to the results of his research, Adi [33] states that the things that can hinder the implementation of managerial competencies among principals include the principal's not having standard competence, lack of experience of the Principal, inability to prepare school plans, lack of coordination and cooperation, lack of school facilities and infrastructure, lack of training, and lack of supervision from superiors.

\section{Conclusions}

Based on the description of the research results, it can be concluded that the principal has been able to build a good school system in improving the quality of education in his school, namely through proper school administration, compiling and implementing school planning, and developing schools according to needs. The steps for performing student discipline at MI Darul Masholeh are through identifying students' negative behavior, making rules, choosing consequences, and consistency in implementing regulations. Meanwhile, supporting factors for the implementation of student discipline in schools include the students' understanding of the importance of being disciplined, the role of parents in habituating disciplinary attitudes and school encouragement in the implementation of the Smart Indonesia Program (PIP) which has gone quite well. While the inhibiting factor in the application of student discipline at MI Darul Masholeh is the environment around the school which is less concerned about education, still minimal school facilities and a separate and open school building.

\section{Acknowledgements}

We are very grateful to experts for their appropriate and constructive suggestions to improve this article.

\section{REFERENCES}

[1] F. Ozmen and V. Muratoglu, "The competency levels of school principals in implementing knowledge management strategies: The views of principals and teachers according to gender variable," Procedia - Soc. Behav. Sci., vol. 2, no. 2, pp. 5370-5376, 2010.

[2] E. Mulyasa, Menjadi Kepala Sekolah yang Profesional. Bandung: Rosda Karya, 2003.

[3] J. Kassim, J. Ahmad, M. I. M. Hamzah, and J. A. Wahab, "Developing management models in malaysian context for the gallantry of national schools in West Malaysia," Procedia-Soc. Behav. Sci., vol. 28, pp. 217-221, 2011.

[4] Wahjosumidjo, Kepemimpinan Kepala Sekolah; Tinjauan Teoritik dan Permasalahannya. Jakarta: Rajagrafindo Persada, 2008.

[5] B. R. Werang, "Pengaruh Keterampilan Managerial Kepala Sekolah dan Iklim Sekolah Terhadap Komitmen Kerja Guru Sekolah Dasar Kristen di Kabupaten Boven Digoel Basilius Redan Werang*," Al Ibtida J. Pendidik. Guru MI, vol. 5, no. 2, pp. 159-174, 2018.

[6] I. Anwar, Administrasi Pendidikan dan Manajemen Biaya Pendidikan. Bandung: Alfabeta, 2004.

[7] B. Badarrusaleh, "Implementasi Kemampuan Manajerial Kepala Sekolah pada Sekolah-Sekolah Umum YPS Soroako Kecamatan Nuha Kabupaten Luwu Timur," Universitas Negeri Makassar, 2014.

[8] T. Tu'u, Peran Disiplin Pada Perilaku dan Prestasi Belajar Siswa. Jakarta: PT Raja Grasindo Persada, 2004.

[9] Gunarsa, Psikologi Perkembangan Anak dan Remaja. Jakarta: Gunung Mulia, 2008.

[10] Suradi, "Pembentukan Karakter Siswa melalui Penerapan Disiplin Tata Tertib Sekolah," Briliant J. Ris. dan Konseptual, vol. 2, no. 4, pp. 522-533, 2017.

[11] A. Rofii’uddiin, “Kedisiplinan Siswa dalam Mengikuti Kegiatan Sekolah ( Studi Kasus di SD Negeri Panasan Sleman)," J. Pendidik. Guru Sekol. Dasar, vol. 5, no. 15, pp. 397-407, 2016.

[12] N. Efendi, Islamic Educational Leadership; Memahami Integrasi Konsep Kepemimpinan di Lembaga Pendidikan Islam. Yogyakarta: Kalimedia, 2017.

[13] M. Wulandari, "Upaya Meningkatkan Kedisiplinan Siswa Melalui Pendidikan Kewarganegaraan," J. Ilm. PPKn, vol. 2, no. 1, pp. 44-53, 2014.

[14] E. S. Ariananda, S. Hasan, and M. Rakhman, "Pengaruh Kedisiplinan Siswa di Sekolah terhadap Prestasi Belajar Siswa Teknik Pendingin," J. Mech. Eng. Educ., vol. 1, no. 2, pp. 233-238, 2014.

[15] Sugeng, "Pengaruh Kompetensi Manajerial Kepala Sekolah dan Budaya Sekolah terhadap Kinerja Guru SMP Negeri di Kabupaten Kudus," Educ. Manag., vol. 1, no. 1, pp. 63-70, 
2012.

[16] H. Iriawan, "Pengaruh Kompetensi Manajerial Kepala Sekolah terhadap Kompetensi Sosial Guru Di SMA Negeri 11 Makassar," J. Ilm. Ilmu Adm. Publik, vol. 7, no. 2, pp. 59-68, 2017.

[17] F. Rohman, "Peran Pendidik dalam Pembinaan Disiplin Siswa di Sekolah / Madrasah," Ihya al-Arabiyah J. Pendidik. Bhs. dan Sastra Arab, vol. 4, no. 1, pp. 72-94, 2018.

[18] F. J. Fiana and M. Ridha, "Disiplin Siswa di Sekolah dan Implikasinya dalam Pelayanan Bimbingan dan Konseling," KONSELOR J. Ilm. Konseling, vol. 2, no. 231, pp. 26-33, 2013.

[19] Latifah and I. Nuraida, "Pengaruh Keteladanan Guru Madrasah Ibtidaiyah terhadap Perilaku Disiplin Peserta Didik di MI Negeri Manis Kidul Kecamatan Jalaksana Kabupaten Kuningan," Al Ibtida J. Pendidik. Guru MI, vol. 1, no. 2, 2014.

[20] Sugiyono, Metode Penelitian Kuantitatif, Kualitatif dan $R \& D$. Bandung: Alfabeta, 2017.

[21] M. B. Miles, A. M. Huberman, and M. Huberman, M. A., Huberman, Qualitative data analysis: An expanded sourcebook. sage, 1994.

[22] A. Wallapha, N. Pennee, and S. Utis, "An Educational Management of Alternative Schools in Northeastern Thailand: Multi-cases Study," Procedia - Soc. Behav. Sci., vol. 116, pp. 1001-1005, 2014.

[23] T. M. Huang, "The relationship between headmasters' leadership behaviour and teachers commitment in primary schools in the district of Sarikei, Sarawak," Procedia - Soc. Behav. Sci., vol. 29, pp. 1725-1732, 2011.

[24] S. Lourmpas and A. Dakopoulou, "Educational Leaders and Teachers' Motivation for Engagement in Innovative Programmes. The Case of Greece," Procedia - Soc. Behav. Sci., vol. 116, pp. 3359-3364, 2014.

[25] A. Androniceanu, B. Ristea, and M. M. Uda, "Leadership Competencies for Project Based School Management Success," Procedia - Soc. Behav. Sci., vol. 182, pp. 232 $238,2015$.

[26] R. Kaçmaz and C. Serinkan, "Human Resource Management Practices in International Sebat Educational Schools," Procedia - Soc. Behav. Sci., vol. 116, pp. 4809-4813, 2014.

[27] T. K. Ngang, S. H. Mohamed, and S. Kanokorn, "Soft Skills of Leaders and School Improvement in High Performing Schools," Procedia - Soc. Behav. Sci., vol. 191, pp. $2127-$ 2131, 2015.

[28] G. V. S. Vally and K. Daud, "The Implementation of School Based Management Policy: An Exploration," Procedia Soc. Behav. Sci., vol. 172, pp. 693-700, 2015.

[29] P. Thanomwan and P. Buncha, "Relationship between Organization Culture and Sufficiency School Management," Procedia - Soc. Behav. Sci., vol. 116, pp. 796-801, 2014.

[30] L. J. Koening, Smart Discipline; Menanamkan Disiplin dan Menambakan Rasa Percaya Diri Pada Anak. Jakarta: Gramedia Pustaka Utami, 2003.

[31] S. Moradi, S. Bin Hussin, and N. Barzegar, "School-Based
Management (SBM), Opportunity or Threat (Education systems of Iran)," Procedia - Soc. Behav. Sci., vol. 69, pp. 2143-2150, 2012.

[32] Slameto, Belajar dan Faktor-Faktor yang Mempengaruhinya. Jakarta: Rineka Cipta, 2010.

[33] A. Adi, "Implementasi kompetensi manajerial kepala sekolah kecamatan Kuala Kampar Kabupaten Pelalawan Propinsi Riau.," J. Akuntabilitas Manaj. Pendidik., vol. 4, no. 1, pp. 1-16, 2016. 